\title{
Design of Savonius Vertical Axis Wind Turbine for Vehicle
}

\author{
Filian Arbiyani*, Fernando Pranata Lasut \\ Department of Mechanical Engineering, Atma Jaya Catholic University of Indonesia, \\ Jl. Jend. Sudirman No.51, Jakarta, 12930, Indonesia \\ *Corresponding author: f.arbiyani@atmajaya.ac.id
}

\begin{abstract}
The use of cellular phones is increasing in society, but due to the limited battery capacity of cell phones, it is necessary to charge the battery when travelling in the long distances. The Savonius type wind turbine has a potential as an energy source harvesting the wind energy flowing around the car. However, due to the available space on the car, careful design of Savonius vertical axis wind turbine for vehicle is necessary. The research is conducted numerically using MATLAB software. The wind speed, Reynolds number, and electric power output are numerically simulated to obtain the swept area design. Innovative PLA material in the design is also investigated by simulating the effect of mass inertia moment to the design. This design of Savonius vertical axis wind turbine for vehicle is expected to charge maximum four cell phone batteries with the total electrical output of $60 \mathrm{~W}$. The optimum swept area design of Savonius vertical axis wind turbine for vehicle is $0.150 \mathrm{~m}^{2}$ using 3 fins, PLA filament material, with an overlap of $5.3 \mathrm{~cm}$, and a diameter for each blade $22 \mathrm{~cm}$ according to the overlap ratio used of 0.242. This Savonius vertical axis wind turbine design is feasible as an energy source for vehicle owing to its compact design, innovative material used in the design, and providing the electric power demand in the vehicle.
\end{abstract}

Copyright (C) 2020. Journal of Mechanical Engineering Science and Technology.

All rights reserved.

Keywords: MATLAB, savonius, vehicle mounted wind turbine, vertical axis wind turbine, wind turbine.

\section{Introduction}

In the digital era, electronics devices are highly used, including a cell phone or smart phone as a basic need for distance communication. Cell phones use battery as an energy source and it always must be recharged. Cell phones or smart phones becomes a basic need, and everyone always bring their smartphones while travelling, including while travelling by vehicle, such as a car. Travelling in the long journey sometimes need the smartphones to be recharged.

There are numerous kinds of renewable energy. One of them is a wind energy. Travelling by vehicle, such as a car, has an enormous potency of a wind energy. Therefore, by implementing a Savonius vertical axis wind turbine on a vehicle, one can harvest this energy resources.

A Savonius vertical axis wind turbine operates using the drag force, and the highest drag force can be attained by placing the wind turbine on top of the car cabin [1]. A Savonius vertical axis wind turbine takes advantage from the car velocity to gain the maximum wind force, which then connected to the power generator.

In general, to obtain the maximum electric power output, the swept area of wind turbine has to be designed as big as possible. However, there is a limit space of the car cabin rooftop 
while implementing the Savonius vertical axis wind turbine on a vehicle. The maximum swept area is $0.25 \mathrm{~m}^{2}$ with the ratio of height $(\mathrm{H})$ and diameter $(\mathrm{D})$ is $1: 1$. The maximum swept area is determined based on the shortest length of the common vehicle, while the height and diameter are determined based on the Regulation from Ministry of Transportation Republic of Indonesia. The length is $0.922 \mathrm{~m}$ from the size of rooftop pick-up vehicle Daihatsu Granmax [2], and the height and diameter size are $0.98 \mathrm{~m}$ [3]. Further safety consideration is also applied by implementing half size from the maximum available space in the design, i.e. $0.5 \mathrm{~m}$ for the height and diameter, thus the design for maximum swept area is $0.25 \mathrm{~m}^{2}$.

Based on the available maximum swept area, careful design of a Savonius vertical axis wind turbine is conducted numerically using MATLAB software. The wind speed, Reynolds number, and electric power output are numerically simulated to obtain the optimum swept area design. Innovative PLA material in the design is also investigated by simulating the effect of mass inertia moment to the design.

\section{Material and Methods}

There are four parameters used to determine the design of Savonius vertical axis wind turbine for vehicle, i.e. car velocity which also represents the wind speed, Reynolds number, electric power output, and mass inertia moment. The study was conducted numerically using MATLAB software.

\section{A. Car/Vehicle Velocity $(U)$}

The car velocity values were range from $40 \mathrm{~km} /$ hour to $80 \mathrm{~km} / \mathrm{hour}$. These values are allowable car speed in a highway or express way. In aerodynamic, a car velocity would be assumed as a representative of a wind speed. Therefore, this parameter would determine the swept area design according to Eq. (1).

$P_{w}=\frac{1}{2} \times \rho \times A \times U^{3}(W)$

where: $\quad P_{w}:$ Wind power $(\mathrm{W})$

$\rho$ : Density $\left(\mathrm{kg} / \mathrm{m}^{3}\right)$

A : Swept area $\left(\mathrm{m}^{2}\right)$

$\mathrm{U}:$ Wind speed $(\mathrm{m} / \mathrm{s})$

with the air density of $1.293 \mathrm{~kg} / \mathrm{m}^{3}$ at air standard condition [4].

The swept area design can be seen in Figure 1, and its calculation using Eq. (2).

$A=H \times D$

where: A : Swept area $\left(\mathrm{m}^{2}\right)$

$\mathrm{H}$ : Height wind turbine (m)

D : Diameter $(\mathrm{m})$ 

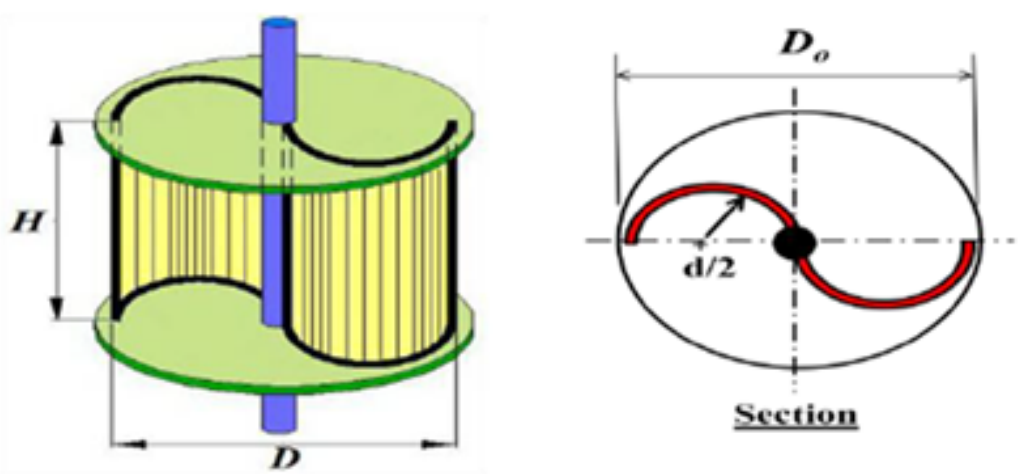

Fig. 1. Swept area design of Savonius vertical axis wind turbine

\section{B. Reynolds number (Re)}

The air flow at the surface of the wind turbine blade is assumed as an external flow at flat plate. At this phenomenon, Reynolds number of $5 \times 10^{5}$ and higher will result in turbulence flow.

Reynolds number is simulated using Eq. (3).

$$
R e=\frac{U \times D}{v}
$$

where: $U$ : Wind speed $(\mathrm{m} / \mathrm{s})$

D : Diameter (m)

$\mathrm{v}:$ Kinematic viscosity $\left(\mathrm{m}^{2} / \mathrm{s}\right)$

with the kinematic viscosity of $1.56 \times 10-5 \mathrm{~m}^{2} / \mathrm{s}$ at air standard condition [4].

\section{Electric Power Output (Pe)}

The electric power output of Savonius vertical axis wind turbine (Pe) is a results process as can be seen in Figure 2.

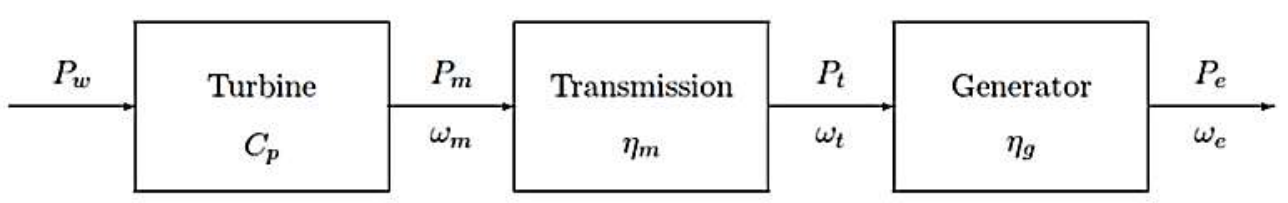

Fig. 2. Main component of a wind turbine

The electric power output (Pe) is obtained using Eq. (4). The generator efficiency $\left(\eta_{\mathrm{g}}\right)$, swept area $(\mathrm{A})$, transmission efficiency $\left(\eta_{\mathrm{m}}\right)$, and the wind speed $(\mathrm{U})$ are determined based on the various vehicle velocity with the performance coefficient $\left(C_{p}\right)$ of 0.2 [6].

$$
P_{e}=C_{p} \times \eta_{m} \times \eta_{g} \times \frac{1}{2} \times \rho \times A \times U^{3}(\mathrm{~W})
$$

The generator efficiency $\left(\eta_{\mathrm{g}}\right)$ was calculated using Eq. (5)...

$$
\eta_{g}=\frac{X-(0.5) Y(1-Y)\left(X^{2}+1\right)}{X}
$$

with $X$ and $Y$ variable were calculated using Eq. (6) and Eq. (7), respectively. 
$Y=0.05\left(\frac{10^{6}}{P_{e R}}\right)^{0.215}$

In this design, the output power of the generator used is $100 \mathrm{~W}$. This generator specification was set as the maximum electric power output $\left(\mathrm{P}_{\mathrm{eR}}\right)$.

$X=\frac{P_{t}}{P_{t R}}$

where: $\mathrm{P}_{\mathrm{eR}}$ : Maximum generator electric power (W)

$\mathrm{P}_{\mathrm{t}} \quad$ : Transmission power $(\mathrm{W})$

$\mathrm{P}_{\mathrm{tR}} \quad$ : Maximum transmission power $(\mathrm{W})$

Since the wind speed affects the mechanical (transmission) power, thus the ratio of $\mathrm{P}_{\mathrm{t}} / \mathrm{P}_{\mathrm{tR}}$ can be assumed as in Eq. (8).

$\frac{P_{t}}{P_{t R}}=\frac{U}{U_{R}}$

where: $U$ : wind speed $(\mathrm{m} / \mathrm{s})$

$U_{R} \quad$ : wind speed at the maximum power $(\mathrm{m} / \mathrm{s})$

The transmission power and the generator efficiency affect the electric power output as can be seen in Eq. (9).

$P_{e}=\eta_{g} \times P_{t}(W)$ (10).

In the transmission section, the transmission efficiency $\left(\eta_{\mathrm{m}}\right)$ can be calculated using Eq.

$\eta_{m}=\frac{P_{m}-(0.02) q \times P_{m R}}{P_{m}}=1-(0.02) q \times \frac{P_{m R}}{P_{m}}$

where: $\mathrm{P}_{\mathrm{m}}$ : Mechanical power $(\mathrm{W})$

$\mathrm{P}_{\mathrm{mR}}$ : Maximum mechanical power $(\mathrm{W})$

q : stage number

This transmission efficiency $(\eta \mathrm{m})$ and the mechanical power $(\mathrm{Pm})$ affect the transmission power $(\mathrm{Pt})$ as can be seen in Eq. (11).

$P_{t}=\eta_{m} \times P_{m}(\mathrm{~W})$

With the mechanical power $(\mathrm{Pm})$ is calculated using Eq. (12).

$P_{m}=C_{p} \times P_{w}(\mathrm{~W})$

with performance coefficient $(\mathrm{Cp})$ of $0.2[6]$ and wind power $\left(P_{w}\right)$ from Eq. (1).

The expected electric power output in this design is $60 \mathrm{~W}$ to recharge the four cell phone batteries [4]. In the power plant, it is wise to provide the electric power output (Pepf) higher than the expected (Pe), thus a power factor (Pf) is applied in this simulation using Eq. (13).

$$
P_{f}=\frac{P_{e}}{P_{e p f}}
$$

Power factor (Pf) of 0.9 is widely used in the electrical distributor company.

\section{Mass Inertia Moment}

The mass inertia moment is calculated using Eq. (14). 
$I=J \times \rho_{a}\left(\mathrm{~kg} \cdot \mathrm{m}^{2}\right)$

where: $\mathrm{J} \quad$ : Area inertia moment $\left(\mathrm{m}^{4}\right)$

$\rho$ : Density of the area $\left(\mathrm{kg} / \mathrm{m}^{2}\right)$

The area inertia moment $(\mathrm{J})$ can be calculated using Eq. (15).

$J=\frac{\pi \times r^{4}}{2}\left(\mathrm{~m}^{4}\right)$

where: $\mathrm{r}$ : radius $(\mathrm{m})$

Density of the area ( $\rho a)$ is determined using Eq. (16).

$\rho_{a}=l \times \rho\left(\mathrm{kg} / \mathrm{m}^{2}\right)$

where: 1 : length $(\mathrm{m})$

\section{$\rho \quad$ : Material density $\left(\mathrm{kg} / \mathrm{m}^{2}\right)$}

In this Savonius vertical axis wind turbine for vehicle design, there are three (3) materials for the options, including an innovative PLA filament material produced by advanced technology of 3D printer. The material density is shown in Table 1.

Table 1. Material density

\begin{tabular}{lr}
\hline Material & Density $\left(\mathrm{kg} / \mathrm{m}^{3}\right)$ \\
\hline Aluminum 6061 [8] & 2700 \\
Low carbon steel AISI 1018 [9] & 7870 \\
PLA Filament [10] & 1240 \\
\hline
\end{tabular}

This mass inertia moment would affect the blades movement of a wind turbine, therefore the proper material chosen is necessary in the design.

Besides the four parameters above, there are another parameter that are also important in designing a Savonius vertical axis wind turbine for vehicle. These parameters are the overlap (e) and diameter size for each blade (d) as can be seen in Figure 3.

The optimum overlap ratio (e/d) for Savonius wind turbine is 0.242 [11], and the diameter for each blade can be calculated using Eq. (17).

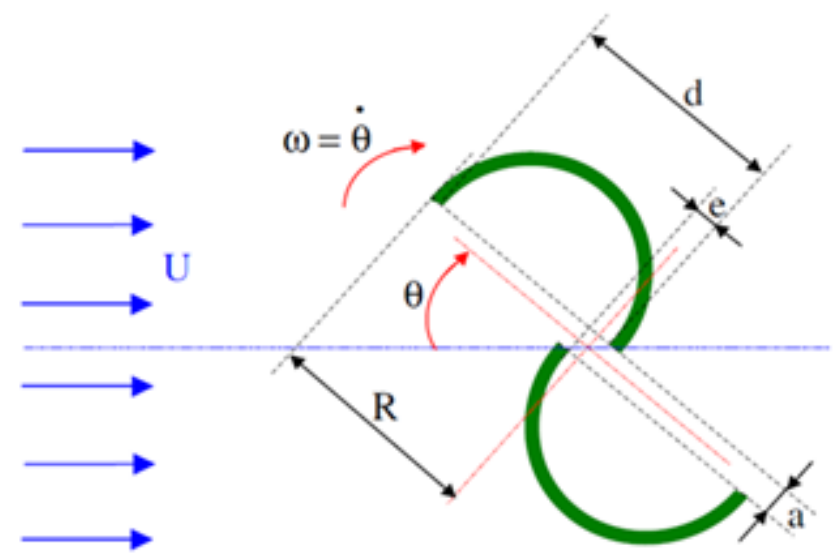

Fig. 3. Schematic drawing of Savonius wind turbine [11] 
$D=e+(2[d-e])(\mathrm{m})$

where: $\mathrm{D}$ : Total diameter $(\mathrm{m})$

d : diameter for each blade (m)

\section{Results and Discussions}

\section{A. Effect of Wind Speed to Swept Area Design}

The effect of wind speed to the swept area design of Savonius vertical axis wind turbine for vehicle can be seen in Figure 4.

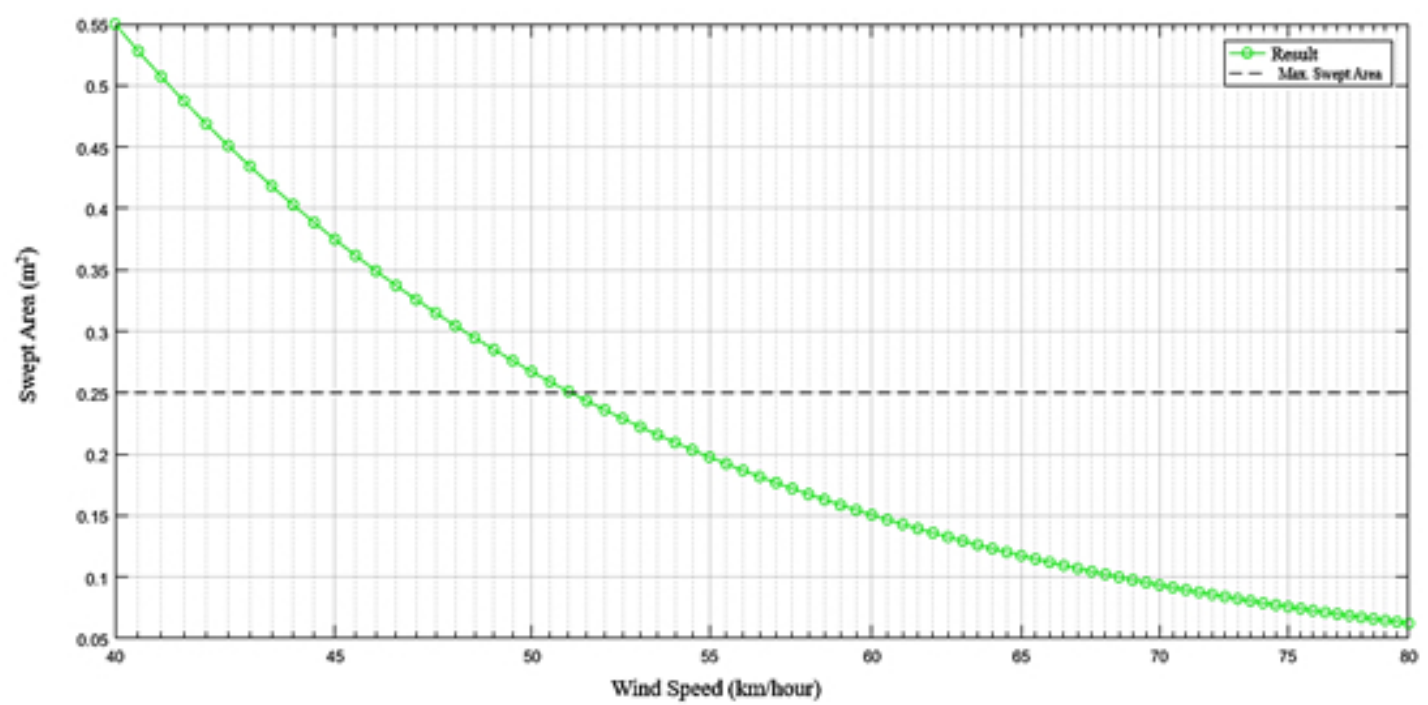

Fig. 4. Effect of wind speed to swept area

As we can see from Figure 4 that the higher wind speed would need smaller swept area. The available maximum swept area on vehicle is $0.25 \mathrm{~m}^{2}$. At this area, the required wind speed is $52 \mathrm{~km} /$ hour which would result in $0.236 \mathrm{~m}^{2}$ of swept area. This wind speed is acceptable as smaller than the available maximum swept area and feasible as a car velocity. Another feasible wind speed which represents the car velocity is $55 \mathrm{~km} / \mathrm{hour}$ which resulted in $0.197 \mathrm{~m}^{2}$ swept area and $60 \mathrm{~km} /$ hour with $0.15 \mathrm{~m}^{2}$ swept area. These three feasible wind speeds and its swept area would then be used as variables to simulate other parameters.

\section{B. Effect of Wind Speed to Reynolds Number}

Based on previous simulation, the three feasible wind speeds of $52 \mathrm{~km} / \mathrm{hour}, 55 \mathrm{~km} / \mathrm{hour}$ and $60 \mathrm{~km} /$ hour would result in $0.236 \mathrm{~m}^{2}, 0.197 \mathrm{~m}^{2}$, and $0.15 \mathrm{~m}^{2}$ swept area design. These three swept areas would then be used to determine Diameter using Eq. (2). Using these diameters at various wind speed would affect the Reynolds number as seen in Figure 5. 


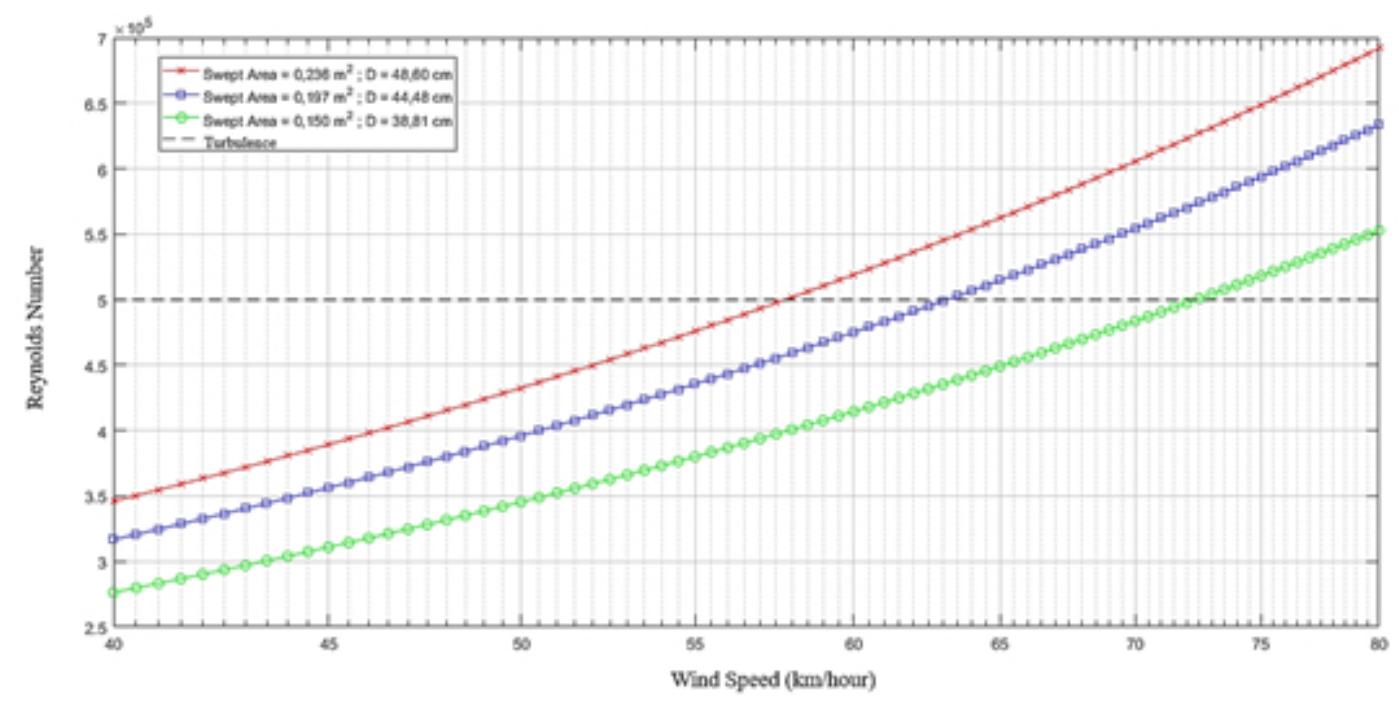

Fig. 5. Effect of wind speed to Reynolds Number

Larger swept area design would rapidly increase the Reynolds number until it reaches the turbulence at Reynolds number of $5 \times 10^{5}$. Higher Reynolds number would affect to higher performance coefficient $\left(\mathrm{C}_{\mathrm{p}}\right)$, thus increasing the electric power output [12]. However, this turbulence might cause the chaotic flow which then would change the wind direction and might break the wind blades for single wind direction. Therefore, the optimum swept area design to prevent this turbulence is $0.15 \mathrm{~m}^{2}$.

\section{Effect of Wind Speed to Electric Power Output}

The swept area design from the feasible three wind speed simulation would be used as variables to simulate the electric power output. The results of wind speed effect to electric power output can be seen in Figure 6.

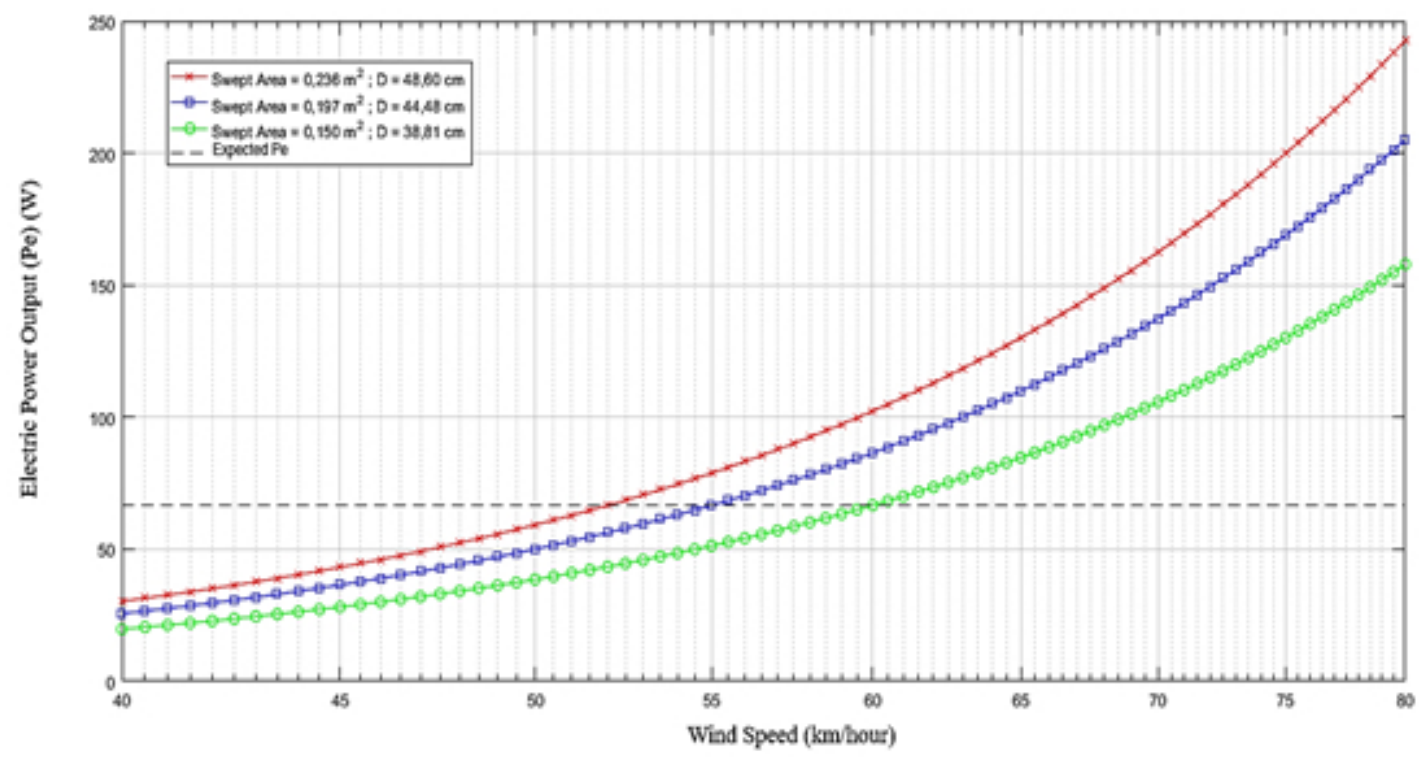

Fig. 6. Effect of wind speed to electric power output 
Higher wind speed with larger swept area design would result in higher electric power output. At the same wind speed, swept area of $0.236 \mathrm{~m}^{2}$ would reach the expected electric power output faster.

\section{Effect of Swept Area Design to Mass Inertia Moment}

Using the density of each material in this design and the radius of the wind blade, the mass inertia moment was obtained as seen in Figure 7.

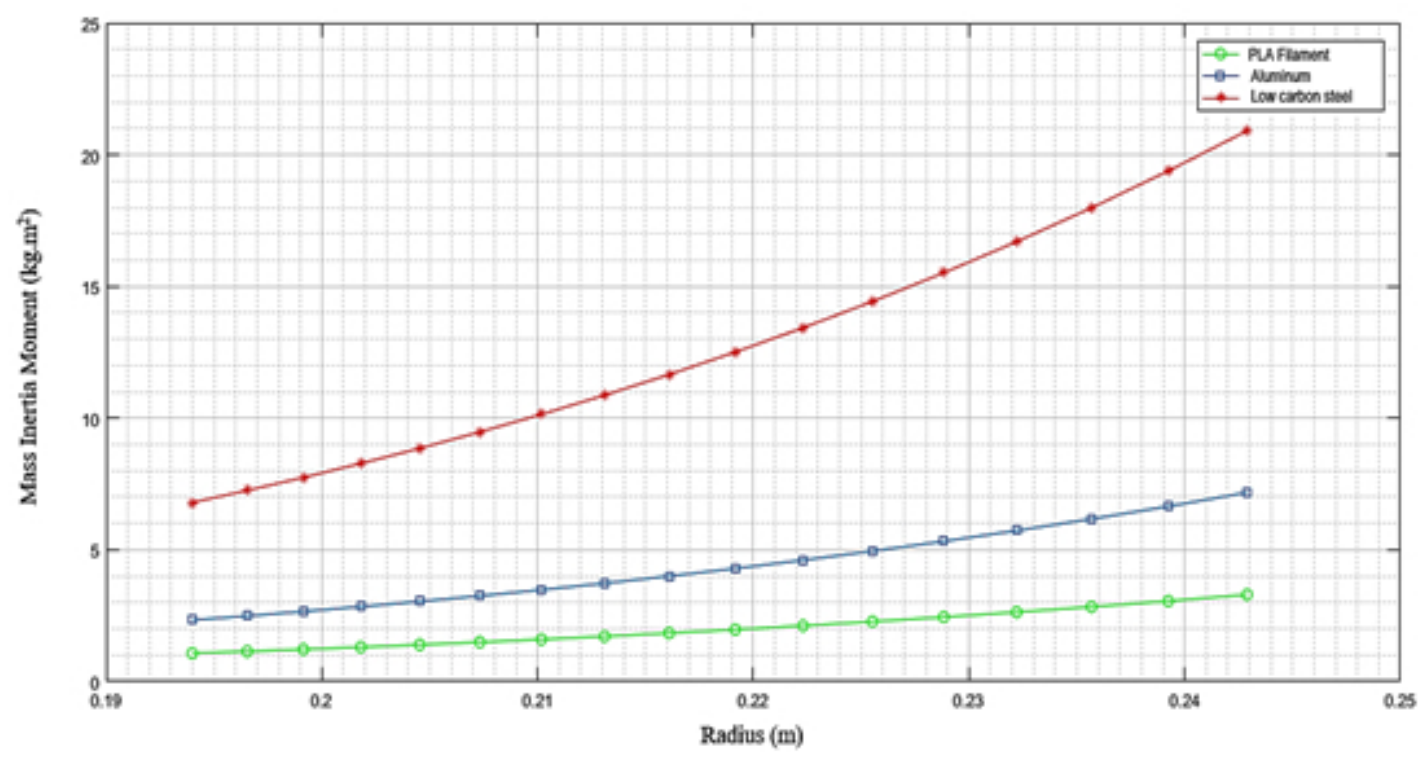

Fig. 7 Effect of swept area design to mass inertia moment

The larger blade radius would result in higher mass inertia moment. This would obstruct the blades movement. Therefore, smaller mass inertia moment would be recommended as a wind turbine material. PLA filament with $0.150 \mathrm{~m}^{2}$ swept area has smallest mass inertia moment.

Based on the four parameters investigated, it was found that the suitable swept area design is $0.236 \mathrm{~m}^{2}$ and $0.150 \mathrm{~m}^{2}$, as seen in Table 2 .

Table 2. Parameters matrix of design Savonius vertical axis wind turbine for vehicle

\begin{tabular}{ccccc}
\hline $\begin{array}{c}\text { Swept Area } \\
\left(\mathrm{m}^{2}\right)\end{array}$ & Wind Speed & $\begin{array}{c}\text { Reynolds } \\
\text { Number }\end{array}$ & $\begin{array}{c}\text { Electric Power } \\
\text { Output }\end{array}$ & $\begin{array}{c}\text { Mass Inertia } \\
\text { Moment }\end{array}$ \\
\hline 0.236 & $\sqrt{ }$ & $\sqrt{ }$ & \\
0.197 & & & & $\sqrt{ }$ \\
0.150 & & $\sqrt{ }$ & & \\
\hline
\end{tabular}

Both swept areas have fulfilled the most required parameters. Finally, swept area design of $0.150 \mathrm{~m}^{2}$ was selected considering the safety application on vehicle and the capability of $3 \mathrm{D}$ printer while using PLA filament as the material.

Furthermore, using Eq. (17), the diameter size for each blade is $22 \mathrm{~cm}$ and $5.3 \mathrm{~cm}$ for the overlap. Additional features of 3 fin were also recommended in the design [13]. The final design of Savonius vertical axis wind turbine on a vehicle was summarized in Table 3 with its implementation on truck model vehicle as shown in Figure 8. 
Table 3. Design of Savonius vertical axis wind turbine on a vehicle

\begin{tabular}{lr}
\hline Design & Size \\
\hline Swept Area $\left(\mathrm{m}^{2}\right)$ & 0.150 \\
Rasio H:D & $1: 1$ \\
Total Height $(\mathrm{cm})$ & 38.81 \\
Total Diameter $(\mathrm{cm})$ & 38.81 \\
Material and Mass Inertia Moment $\left(\mathrm{kg} / \mathrm{m}^{2}\right)$ & Filament PLA; 0.959 \\
Fin & $3[13]$ \\
Overlap Ratio & $0.242[11]$ \\
Overlap $(\mathrm{cm})$ & 5.3 \\
Diameter for each blade $(\mathrm{cm})$ & 22 \\
\hline
\end{tabular}

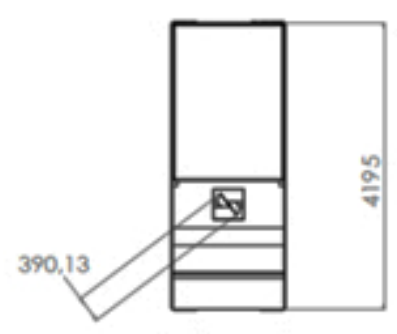

TOP VIEW

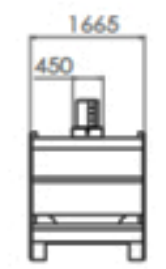

FRONT VIEW
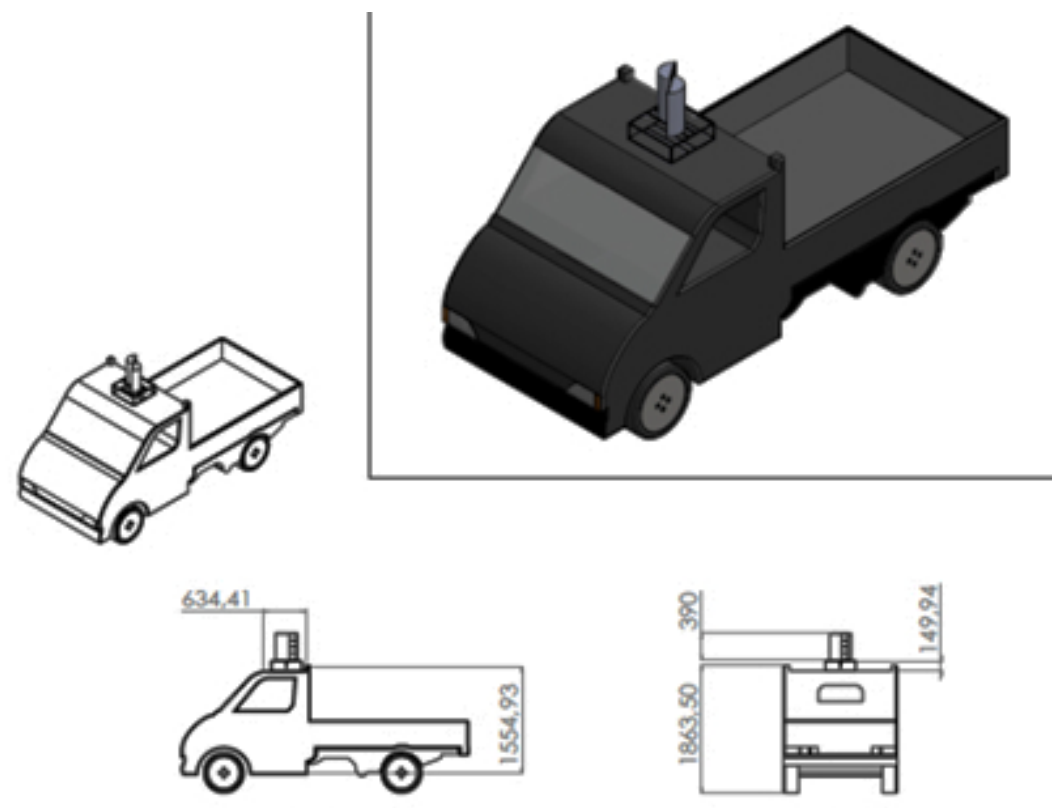

SIDE VIEW

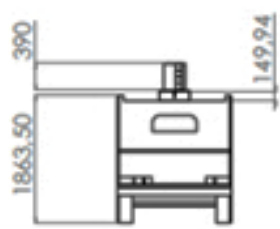

REAR VIEW

Fig. 8 Design of Savonius vertical axis wind turbine for vehicle

\section{Conclusions}

The optimum swept area design of Savonius vertical axis wind turbine for vehicle is $0.150 \mathrm{~m}^{2}$ using 3 fins, PLA filament material, with an overlap of $5.3 \mathrm{~cm}$, and a diameter for each blade $22 \mathrm{~cm}$ according to the overlap ratio used of 0.242 . This Savonius vertical axis wind turbine design is feasible as an energy source for vehicle owing to its compact design, innovative material used in the design, and providing the electric power demand in the vehicle. 


\section{References}

[1] Sofian, M., Nurhayati, R., and Rexca, J., "An Evaluation of Drag Coefficient of Wind Turbine System Installed on Moving Car," Applied Mechanics and Materials, vol. 660, pp. 692-693, 2014.

[2] "Granmax PU," Daihatshu Indonesia. [Online]. Available: https://daihatsu.co.id/product/granmax-pu. [Accessed Nov 21, 2019].

[3] Biro Komunikasi dan Informasi Publik, "Direktorat Jenderal Perhubungan Darat," Kementrian Perhubungan Republik Indonesia, 2018. [Online]. Available: http://www.dephub.go.id/post/read/pastikan-keselamatan-jalan,-kemenhub-aturketentuan-bak-kendaraan-barang. [Accessed Nov 21, 2019].

[4] G. L. Johnson, Wind Energy Systems : Electronic Edition. Manhattan: Kansas State University, 2006.

[5] F. M. White, Fluid Mechanics, Seventh. New York: McGraw-Hill, 2011.

[6] M. Sathyajith, Wind Energy: Fundamentals, Resource Analysis, and Economics. Berlin: Springer, 2006.

[7] Ware, J., "Power Factor Correction (pfc)," Wiring Matters, pp. 23, 2006, doi: 10.1109/T-AIEE.1925.5061090.

[8] B. Toulas, “6061-T6 Aluminium - The Ultimate Guide,” Engineering Clicks, 2017. [Online]. Available: https://www.engineeringclicks.com/6061-t6-aluminum/. [Accessed Jan 10, 2020].

[9] AZoM, “AISI 1018 Mild/Low Carbon Steel," AZO Materials, 2012. [Online]. Available: https://www.azom.com/article.aspx?ArticleID=6115. [Accessed Jan 10, 2020].

[10] "Filament Properties Table," Simplify3D. [Online]. Available: https://www.simplify3d.com/support/materials-guide/properties-table/. [Accessed Jan 10, 2020].

[11] Menet, J.-L. J., Bourabaa, N., "Increase in The Savonius Rotors Efficiency via A Parametric Investigation," in EWEA - 2004 European Wind Energy Conference, April, 2004.

[12] Bachant, P., Wosnik, M., "Effects of Reynolds Number on The Energy Conversion and Near-Wake Dynamics of A High Solidity Vertical-Axis Cross-Flow Turbine," Energies, vol. 9 (2), pp. 2, 2016.

[13] Utomo, I. S., Tjahjana, D. D. D. P., and Hadi, S., "Experimental Studies of Savonius Wind Turbines with Variations Sizes and Fin Numbers Towards Performance," AIP Conference Proceedings, vol. 1931, February, 2018. 